\title{
Denver X-ray conference comments and reflections on current issue of Powder Diffraction Journal (PDJ) - CORRIGENDUM
}

\author{
Camden Hubbard
}

doi: https://doi.org/10.1017/S0885715618000751, Published by Cambridge University Press, 21 November 2018

In Hubbard (2018), the last sentence of the first paragraph was incorrect.

The sentence should read "Further details can be read about in the conference summary included in the next issue of Powder Diffraction Journal (PDJ)".
Hubbard, C. (2018). "Denver X-ray conference comments and reflections on current issue of Powder Diffraction Journal (PDJ)," Powder Diffr. 33, 265. doi:10.1017/S0885715618000751. 